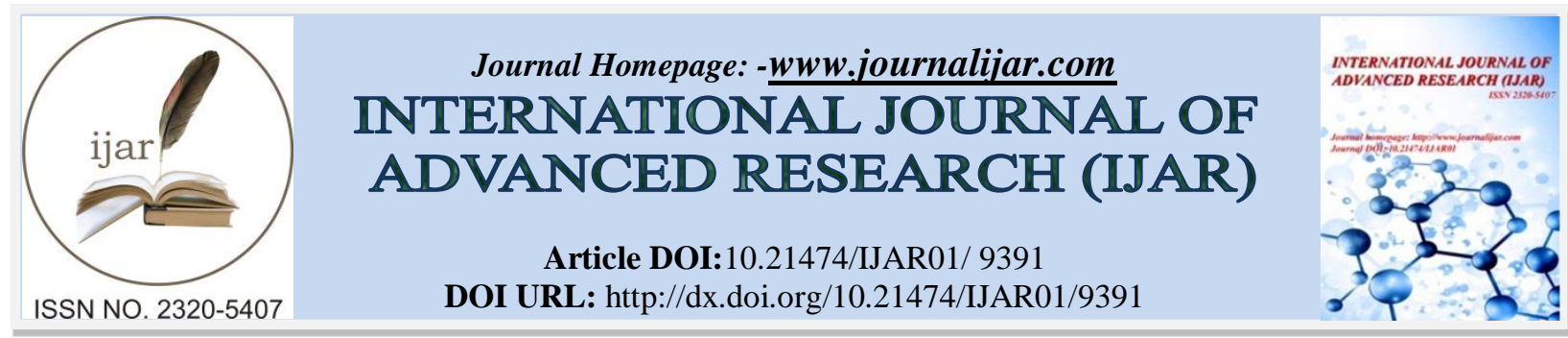

RESEARCH ARTICLE

\title{
VIOLATION OF HOLY SITES IN JERUSALEM.
}

Sabir Ijaz ${ }^{1}$, Mubasshar Hassan Jafri ${ }^{2}$ and Prof. Dr.Summer Sultana ${ }^{3}$.

1. PhD Research scholar, Department of Political Science, University of Karachi.

2. Research Scholar, Center for International Peace and Stability (CIPS) NUST.

3. (Supervisor and Chairperson), Department of Political Science, University of Karachi.

\section{Manuscript Info}

Manuscript History

Received: 15 May 2019

Final Accepted: 17 June 2019

Published: July 2019

Key words:-

Human Rights, Freedom, Religion,

Violations, Restriction, Judaism,

Christianity, Islam,UNGA, UNSC, OIC,

NAM, Arab League UNGA, UNSC,

OIC, NAM, Arab League, ICJ.

\section{Abstract}

Jerusalem is a holy city to hundreds of millions of people around the world from different faiths. For Jews it is the site of Solomon's Temple, and the Jewish bond with Jerusalem has been maintained throughout the generations. Three times each day, Jews turn to face the Western Wall of the Temple when they pray. For Christians, Jerusalem is the city of Jesus' last days. Christians from around the world dream of praying at the Holy Places in Jerusalem. Muslims worldwide yearn for a pilgrimage to Jerusalem, second in importance only to the pilgrimage to Mecca. The Dome of the Rock marks the site of the Prophet Mohammad's ascent to heaven. Local Muslims make a special effort to attend Friday prayers at the al-Aqsa Mosque in Jerusalem, particularly during the holy month of Ramadan.

Copy Right, IJAR, 2019,. All rights reserved.

\begin{abstract}
Introduction:-
Holy land

The "Holy Land" is a term that relates to Palestine, which originated in the Byzantine period, during the 4th c. CE. The holiness attributed to this geographical area by billions of believers around the world has an effect on the Israeli Palestinian conflict, and attracts much international involvement. Most of the holy sites in occupied Palestine, also considered archaeological sites, are holy to more than one religion. The holiness of a place is maintained for years despite ethnic, cultural and religious shifts in the composition of the population (Mack, 2016, p. 5). The city of Jerusalem - in Hebrew Yerushaláyim, meaning City of Peace, and in Arabic Al Quds, meaning the Holy - is referred to as 'the Holy City' worldwide. This is due to its unique amplitude of religious sites of the three monotheistic religions, reflecting that Jerusalem faced the reign of Jews, Christians and Muslims in its more than 3000 -yearold history. While Jerusalem today covers an area of $125,1 \mathrm{~km}$, the Old City, bearing holy sites like the Dome of the Rock, the Western Wall or the Church of the Holy Sepulcher, only amounts to $900 \mathrm{~m}$. With Jews rushing to the Western Wall, Muslims hasting to the Temple Mount and Christians walking down the Via Dolorosa, it is a kaleidoscope of the multi-faith character of the city (Amari, 2009).
\end{abstract}

\section{Significance of the city}

There is perhaps no other city in the world that has drawn the continued attention of the world community as much as the city of Jerusalem, especially among the adherents of the three monotheistic religions: Judaism, Christianity and Islam. The city's religious centrality has generated its historical and political importance, as well as its symbolic 
impact, but its religious position has also been at the root of a considerable controversy. This controversy focuses on who has the greater attachment and entitlement to the city, and for whom Jerusalem has the greatest religious, cultural, historical and political importance: "In all probability one would never be able to gauge the degree of attachment that an individual community feels toward the city, for attachment is psychological and thus highly subjective." While the Muslims, for example, especially Palestinian and Arab Islamists, recognize the religious significance of Jerusalem to Christians and Jews, they stress the Muslim character of the city and Muslim entitlement to it, and their attachment to Jerusalem constitutes part of their doctrinal views of the city (Abu-Amr, 1995).

At the Declaration of after the creation of Israel in Palestinian's land in May 1948 the country's founders made an unequivocal pledge: the Israeli state, they wrote, "will guarantee freedom of religion, conscience, education and culture" and "will safeguard the Holy Places of all religions." This promise was made with a view to allaying international concern that the founding of a Jewish state would lead to the privileging of the holy places of one religion - Judaism - over the two other monotheistic faiths, Christianity and Islam, that count the Holy Land as the cradle of their birth Israel's actions in the intervening 56 years, as this report will show, are evidence that, not only has this promise been ignored, but that in practice the authorities have intentionally and actively encouraged or supported the destruction and abuse of holy places belonging to the Christian and Muslim faiths. The detailed research of the Arab Association for Human Rights (HRA) in Nazareth reveals gross injustice committed by the Israeli authorities since the founding of the Jewish state. There is a long list mosques and churches inside occupied Palestine either destroyed by Israel during and after the 1948 war or made absolutely inaccessible to the local Arab population who once used them. It shows that at least 250 places of worship have suffered such abuse at the hands of Israel (The Electronic Intifada, 2004).

\section{Denial of access}

Many places of worship have been declared "closed zones" which cannot be accessed without special permits, and these permits are never issued to Arab citizens. Other buildings have been made inaccessible simply because their doors and windows have been bricked up, or fences placed around them. At Hittin a steel fence has been erected around the perimeter of the 900-year-old mosque so that it cannot be reached. The gates of the Great Mosque of Bir al-Seba' (Beersheva) have been padlocked even though there is a thriving Muslim population in the city with nowhere else to worship.

Jerusalem is inaccessible to many who wish to worship there. Muslims from a few miles down the road are prevented from praying at the al-Aqsa mosque. During the most recent Ramadan, religious Muslims knelt in prayer at the checkpoints around Jerusalem, after being denied access to the city itself. Palestinian Christians are also prevented from entering the city to pray in the Church of the Holy Sepulcher, the holiest site for Christians. During the most recent celebration of Easter, many Palestinian Christians were refused entry permits. The checkpoints and Barrier around the city also hinder access to neighboring Bethlehem. In fact, once the Barrier is completed, the little town of Bethlehem will be almost entirely surrounded by barbed wire and a concrete wall (BTSELEM, 2006, p. 30). Christians are being denied the right to worship at Christianity's most sacred sites in the Holy Land. This has led to a drastic decline in the Christian population there. The chief cause of the Christian exodus, according to Khader and Kasis, is Israel's illegal occupation of Palestine. Khader, a Catholic pastor, described how during Easter, one of the holiest times of the year for Christians, the sacred Church of the Holy Sepulcher - a site central to Jesus's death, crucifixion and resurrection - resembles a military barracks. Barriers are set up in the early hours of the morning to keep people out of the courtyard of the Church. Israeli army officers are present around the gates of the Old City and passages that lead to the Holy Sepulcher, as well as inside the Church itself and on its roof. These measures restrict freedom of movement for Palestinians, preventing Palestinian Christians from worshipping at the Church during this auspicious period. Even priests are not allowed to move freely. Khader said Palestinian Christians living in Bethlehem (the city of Jesus' birth) - located just ten kilometers from Jerusalem - require special permits from Israeli authorities to enter Jerusalem to worship in the sacred city. Christians from the occupied West Bank and Gaza Strip also cannot enter Jerusalem without an Israeli permit. Christian-owned land has also been confiscated to make way for illegal Israeli settlements (IOL, 2018).

\section{Atmosphere of intimidation}

Christians in Jerusalem's Old City say their presence at the geographical heart of their faith is under threat from intimidation and aggressive property acquisition by hardline Jewish settlers. According to church leaders, priests are being verbally abused and spat at, and property vandalized. Tensions have risen in the Christian and Armenian 
quarters of the $1 \mathrm{sq} \mathrm{km}$ ancient walled city, which includes the Church of the Holy Sepulcher, the holiest place in Christianity where Jesus was believed to be crucified and resurrected. The churches say they are facing onslaught on three fronts: a war of attrition waged by hardline Jewish settlers; unprecedented tax demands by Jerusalem city council; and a proposal to allow the expropriation of church land sold to private developers (Sherwood, 2018).

In many other cases Arab citizens are effectively dissuaded from accessing their holy places because they are now situated in the middle of land that has been transferred to Jewish communities. An atmosphere of intimidation and hostility prevails against Arabs trying to enter these areas. For example, the only way to access the church and mosque in the destroyed village of Suhmata is for visitors to park their cars in a layby by a gate at the entrance to a field of cows belonging to a Jewish farming community and then walk on foot. However, local Arab residents report that cars stopping by the gate have their license plates recorded and their owners risk prosecution.

Israeli measures of installing metal detectors, electronic gates, and other new facts on the ground in the Old City and Al-Aqsa compound are simply a continuation of policies that Israel has been pursuing during the past 50 years of its repressive military rule over the Occupied Palestinian territories, including East Jerusalem. The aim is to expand Jewish-Israeli political, economic and demographic control over the city, while further evicting and dispossessing Palestinians.

"These policies have included the illegal annexation of East Jerusalem and its isolation from the rest of the Occupied Palestinian Territories, discriminatory urban and zoning policies, home demolitions and settlement expansion, residency revocation, and shutting down of Palestinian institutions. All of this is within the context of the growing messianic fanaticism and government support to groups like the Temple Institute, which aim at building a temple in the Noble Sanctuary to replace Al Aqsa mosque (Buttu, 2017).

\section{Holy Places Taken Over by Jewish Extremists}

Jewish settlers groups, usually comprising religious extremists, have been allowed by the authorities to take over mosques or shrines and convert them into Jewish places of worship, even though these sites have never been deconsecrated by the Muslim authorities. A tomb in the al-Nabi Rubin mosque, on the Tel Aviv-Ashdod highway, is now covered in Hebrew script and is used by Jewish worshippers. In June 2004 it was reported that Jewish extremists settlers had broken into the shrine of Sheikh Sima'an, near Kofr Saba, and replaced the Islamic symbols with Jewish ones, refashioned the grave inside to accord with Jewish religious custom and then padlocked the site so they had sole access. Finally they placed signs on neighboring roads to identify the location of the new place of worship.

\section{Demolition as Reprisal}

When worshippers have pressed on with reclaiming holy sites, despite all these obstacles, they have been met with the ultimate reprisal. The former inhabitants of Um al-Faraj, who were expelled from their village north-east of Acre in 1953, campaigned for many years to regain access to their mosque. They also lobbied against its use by a local Jewish farming community, Moshav Ben Ami, as a storage barn. Shortly afterwards, in December 1997, the mosque was destroyed. No one was ever prosecuted, but the former villagers feel sure that the moshav was behind the destruction. Similarly, the mosque at Sarafand was destroyed in July 2000 after the former villagers repaired it and started to use it. And in February 2000, members of Moshav Yashin destroyed the mosque of Wadi Hawarith two weeks after its renovation by Muslims had been completed. In none of these cases was anyone prosecuted. The effect of these unofficial demolitions has been to dissuade Muslim and Christian worshippers from pressing their claims to holy sites.

Since Israel takeover of Jerusalem, Israel has engaged in wholesale demolition of sacred sites, destruction of entire historic neighborhoods, displacement of local residents who trace their roots in the city back generations, and the imposition of widespread restrictions on the rights of Muslim and Christian worshippers to access their holy sites (Balousha, 2018). Israeli authorities have separated the city from its Palestinian hinterland through the imposition of a complex system of military checkpoints and permits, preventing their access and thus isolating these sites from the very communities whose identities are based on those holy places. As a result, the majority of Palestinians, Muslims and Christians in the West Bank and Gaza are prevented from accessing the city and its holy sites. A 2011 US State Department report decried Israeli restrictions on Palestinian freedom of worship, noting: "Strict closures and curfews imposed by the Israeli government negatively affected residents' ability to practice their religion at holy 
sites, including the Church of the Holy Sepulcher and al-Aqsa Mosque in Jerusalem, as well as the Church of the Nativity in Bethlehem" (Shams, 2017).

As a result, holy places are being allowed to deteriorate and fall into disrepair. The Catholic church in al-Bassa has already lost its second floor, and the rest is near collapse. At Suhmata in the northern Galilee the church and mosque are roofless shells. Nothing is also being done to prevent the recurring vandalism inflicted on these sites. Many have spray-paint across their walls saying "DEATH TO THE ARABS". State officials appear uninterested in protecting these sites on behalf of their worshippers, and the police never bring prosecutions. In March 2004 arsonists set fire to the Forty Mosque in Beit Shean, which is now under the responsibility of the Public Parks Authority. There was extensive damage, including to the roof, which collapsed. When Muslim officials tried to photograph the damage they had their identity cards confiscated by the police. It was also reported in June 2004 that a resident of Tiberias tried to set fire to al-Omery Mosque in the city center with a Molotov Cocktail, as he shouted: "I don't want to see Arabs or Muslims before my eyes... I will burn the lot of them!" There have been repeated attempts to burn down al-Omery Mosque and the neighboring al-Bahar Mosque in Tiberias.

\section{Conclusion:-}

Undoubtedly the Holy City of Jerusalem, is under grave danger, even as the Judeo-Zionists, Judaising Jerusalem, deepening their control over the Holy City. The so-called Trump declaration on Jerusalem, to the Israeli Nation State law, both have exposed the Zio-Fascist Nazi character of the occupation of Palestine. The World has condemned Israel and US for their refusal to adhere to International law and UN Resolutions and both these Imperialist nations stand exposed and isolated. But the Israeli occupation continues to deepen its presence in West Jerusalem, even as they have begun the eviction of Palestinians from East Jerusalem. The Zionist plans are clear. They intend to take over all of historic Palestine and have no interest in peace or a just solution. The ethnic cleansing of the Palestinian population continues unabated as the World looks on. Yet, despite all the odds, the suffering - yet the Palestinian people carry on to resist the occupation. Of a matter of great urgency is to now defend the Holy City of Jerusalem, to defend all Christian, Muslim and Jewish Holy Sites.

As Muslims we respect all the 3 great Abrahamic faiths of Judaism, Christianity and Islam. As Muslims we revere all the Holy Books and revere all the Prophets. Today Zionism, an ideology of ethno-religious supremacism poses a threat to all of West Asia, the entire world and thus must be defeated. If not the consequences for Humanity will be disastrous. The Judeo-Zionists have clear stated intentions of destroying the Holy Al Aqsa and the Qubatus Sakhra. They have announced that they intend to rebuild the Third Temple on the Haram Al Sharif, after the destruction of the holy and revered Islamic Mosques. The Zionists also have plans to destroy the Holy Church of the Sepulcher, the most Holy Christian site. Netanyahu had threatened that the Al Qaeda had plans to destroy the Church of the Holy Sepulcher. We are all aware of the penetration of the Israeli secret service Mossad within these terror networks. Thus a False Flag Terror operation, targeting the Holy Mosques and/or Churches can, or finally will be carried out by Mossad agents posing as Al-Qaeda or ISIS terrorists.

The World must also take note of the fact that the very foundations of the 2 Holy Mosques has been considerably weakened. The Israelis have been removing the soil from below the Haram Sharif. Today both the Al Aqsa and the Qubattus Sakhra can be easily destroyed by a minor detonation sending tremors, leading to the collapse of the 2 Masjids. Israel is only waiting for the right strategic time. The plans are well in place.

Even as we approach Christmas, the Palestinian Christians of Gaza are not being permitted to travel to Bethlehem and pray at the Church of Nativity, the birthplace of Prophet Jesus Christ. Today the most Holy City of Bethlehem, of all of Christendom stands surrounded by the monstrous Apartheid Wall. Even in Hebron, the Holy Ibrahimi Mosque is under attack by Jewish fanatics.

Yet Western Christendom stands silent. Even as Christian Zionism is guilty of collaborating with the Israeli occupation in the very destruction of Christians and Christianity from the land of its birth, the birthplace of Prophet Jesus himself. We as Muslims must also be honest enough to state that unfortunately today, there are certain Islamic regimes that too are collaborators with Israel. They have abandoned the cause of Jerusalem, of Palestine for their selfish petty ends and they must be condemned by one and all. The Global forces of resistance must stand united to defeat the nefarious Imperialist Zionist designs.

The World is thus witness to the destruction of Palestine, of Jerusalem, it's great religions and it's unique place in the history of humanity. Many greatest Prophets and Saints have walked across the land of Palestine and preached their 
message of the One Merciful Loving God, the message universal compassion and justice, equality, love and peace for all of humanity. Today the land of Peace stands occupied by the evil forces of hate, violence and wars. Jerusalem, the city of universal peace is under grave attack. It's time for Humanity to rise as one and protect our common civilizational heritage. The city is sacred for all the 3 great Abrahamic faiths, namely Judaism, Christianity and Islam and we as believing Muslims recognise and have always respected this fact.

The Zionist plans to destroy the Holy Muslim and Christian sites will surely lead to War, in fact World War 3. These plans are based on an Apocalyptic visions of death and destruction, of ARMAGEDDON, killing billions, a human genocide beyond proportions. It is thus our responsibility as good Muslims, as good Humans to save Jerusalem, to save Palestine - and thus the World!! We must make the World aware of the threat that the fanaticism of Zionism poses to the World.

Thus a High Powered Committee of leading citizens of the World, across religions, to include all those who stand with the Palestinian cause - must be constituted. This committee must undertake a detailed study of the clear and present danger that Zionism poses to the very existence of the Holy Muslim and Christian Holy Sites and further present the report to the UNGA, UNSC, OIC, NAM, Arab League, the International Court of Justice, and all major international institutions and forums. This must be done at once, so as to expose Israel and it's nefarious plans. Today as Muslims it is our duty to defend the Holy land of Palestine, defend Holy Jerusalem. The day is not far when Palestine will be free!

End.

\section{References:-}

1. AALEP. (2017). Jerusalem under International Law. Retrieved December 6, 2018, from http://www.aalep.eu/jerusalem-under-international-law

2. Abu-Amr, Z. (1995). The Significance of Jerusalem: A Muslim Perspective. Retrieved December 8, 2018, from http://www.pij.org/details.php?id=646

3. Amari, C. (2009). Religious Narratives on Jerusalem: Potential for Moderation in the Tense Relationship between Religion and Politics? Retrieved December 18, 2018, from https://www.kas.de/c/document_library/get_file?uuid=673202bd-6cad-d46a-fddc3836244156ea\&groupId $=252038$

4. Balousha, H. (2018). Palestinians mark Christmas amid Israeli restrictions. Retrieved December 28, 2018, from http://www.arabnews.com/node/1425411/middle-east

5. BTSELEM. (2006). A Wall in Jerusalem: Obstacles to Human Rights in the Holy City. Retrieved December 4, 2018, from https://www.btselem.org/download/200607_a_wall_in_jerusalem.pdf

6. Buttu, D. (2017). Religious restrictions in Jerusalem. Retrieved December 12, 2018, from https://medium.com/@thepalestineproject/religious-restrictions-in-jerusalem-a7d173bec3fe

7. Dumper, M., \& Larkin, C. (2009). Political Islam in Contested Jerusalem: The Emerging Role of Islamists from $\begin{array}{lllll}\text { within } & \text { Israel. } & \text { Retrieved } & \text { December } & 2,\end{array}$ http://www.conflictincities.org/pdfs/workingpaper12_10.11.09.pdf

8. IOL. (2018). Christians no longer welcome in Israel, says Palestinian group. Retrieved December 23, 2018, from https://www.iol.co.za/news/world/christians-no-longer-welcome-in-israel-says-palestinian-group16190697

9. Mack, E. (2016). Selectively Sacred: Holy Sites in Jerusalem and its Environs. Retrieved December 1, 2018, from http://alt-arch.org/en/wp-content/uploads/2016/04/28-Holy-places-Eng-WEB.pdf

10. Shams, A. (2017). How Israeli control over Jerusalem destroyed its holiest sites. Retrieved December 11, 2018, from https://www.middleeasteye.net/opinion/how-israeli-control-over-jerusalem-destroyed-its-holiest-sites

11. Sherwood, H. (2018). Christians in Jerusalem's Old City 'under threat' from settlers. Retrieved December 6, 2018, from https://www.theguardian.com/world/2018/may/01/christians-in-jerusalems-old-city-under-threatfrom-settlers

12. The Electronic Intifada. (2004). HRA releases report on Israeli violations against Christian, Muslim holy places. Retrieved December 6, 2018, from https://electronicintifada.net/content/hra-releases-report-israeli-violationsagainst-christian-muslim-holy-places/420

13. The Applied Research Institute Jerusalem. (2012). Jerusalem 'Old City' Profile. Retrieved December 3, 2018, from http://vprofile.arij.org/jerusalem/pdfs/vprofile/jerusalemtheoldcity.pdf 
14. United Nations. (1949). 4General Armistice Agreement between the Hashemite Jordan Kingdom and Israel 1949. Retrieved December $\quad$ 7, from https://unispal.un.org/DPA/DPR/unispal.nsf/0/F03D55E48F77AB698525643B00608D34

15. United Nations. (1949). Draft proposal for an international regime for Jerusalem- UNCCP's Cttee on Jerusalem - working paper prepared by the Secretariat. Retrieved December 4, 2018, from https://www.un.org/unispal/document/draft-proposal-for-an-international-regime-for-jerusalem-unccp-s-ctteeon-jerusalem-working-paper-prepared-by-the-secretariat/. 